\title{
Impact of Overfishing on Density and Test-Diameter Size of the Sea Urchin Tripneustes gratilla at Wakatobi Archipelago, South-Eastern Sulawesi, Indonesia
}

\author{
La Nane* and Arfiani Rizki Paramata \\ Department of Aquatic Resources Management, Faculty of Fisheries and Marine Sciences, \\ Universitas Negeri Gorontalo \\ J. Jend. Sudirman No.6, Dulalowo Timur, Gorontalo, 96128 Indonesia \\ Email: lanane@ung.ac.id
}

\begin{abstract}
Sea urchin Tripneustes gratilla is one of an economically important fisheries resource product for localities at Wakatobi archipelago. High demands for sea urchin gonad have intensified high fishing activity. The hypothesis of this study is that sea urchins in Wakatobi have been overfished. To answer that hypothesis, the density and its test diameter size were measured at two different sites. Those two sites are Pulau Tomia (resident area) and Pulau Sawa (nonresident area and very distant from the localities). The results show that sea urchin density and its test diameter are significantly different. The densities (mean士SE) T. gratilla at Pulau Sawa and Pulau Tomia were $10 \pm 0.6$ (ind. $\mathrm{m}^{-2}$ ) and $2.7 \pm 0.9$ ind. $\mathrm{m}^{-2}$, respectively. Moreover, the test diameter at Pulau Sawa and Pulau Tomia were $69.7 \pm 2.1 \mathrm{~mm}$ and $58.5 \pm 1.7 \mathrm{~mm}$ (mean $\pm S E$ ), respectively. These results have shown that overfishing has occurred. Therefore, sea urchin with test diameter 66-75 mm, 76-85 mm, and 86-95 $\mathrm{mm}$ have disappeared at Pulau Tomia. The conclusion reveals that fishing of sea urchin Tripneustes gratilla at Pulau Tomia has been overfished.
\end{abstract}

Keywords: density, test diameter, sea urchin, overfishing, Wakatobi

\section{Introduction}

Sea urchins have been known as major ecologically important components, especially in shallow tropical seas (Steneck, 2013; Luja and Malay, 2019). They also have played a crucial rule in nutrient cycling, macroalgal grazing, and bioerosion (Koike et al., 1987; Bronstein and Loya 2014; Ling et al., 2018). The roe (gonad) of sea urchins have been utilized as seafood products in many parts of the world, particularly Asia and Europe (Baião et al., 2019; Kato, 1972; Salvo et al., 2016; Taylor et al., 2017). Thereby, sea urchin gonads have highly valued commercially (Lawrence, 2007; Brown and Eddy, 2015; Sun and Chiang, 2015). As a consequence, demand on sea urchin gonads is rapidly increased globally (Brown and Eddy 2015, Mos and Dworjanin, 2019). However, that high demands have eased the capture of sea urchin, and the long recruitment time has also caused the loss of wild populations of sea urchin (Sloan 1985; Keesing and Hall 1998; Lesser and Walker 1998; Andrews et al., 2002; Robinson, 2004).

In Wakatobi Archipelago, Sea urchin Tripneustes gratilla is an economically important fisheries resource product that has been fished traditionally for commercial purposes for the years. However, globalization that followed with a high birth- rate of humans at Wakatobi, demand for sea urchin gonad, has also increased. As a consequence, sea urchin numbers in the wild nature decreased gradually. Moreover, the number of individuals of sea urchin at fishing ground seems to be low in number and to be small in test-diameter size. However, nobody knows why and what the causes of those symptoms.

Sea urchins as the natural resources could be overexploited by high fishing pressure. Decreasing sea urchin at nature may be related to the fishing activity that has been intensified since the last decade. Unfortunately, there is no fishing data that have been documented on decreasing $f$ sea urchin, including the number of fishers that depend on that fishing. However, fishing of sea urchins has significantly triggered the number of fishing gears application and fishing boat quantity. As a result, intense fishing trips to catch sea urchins have also increased. In parallel with that, the total harvest to sea urchins is also large in quantities.

On the other hand, sea urchin stock is not only limited in number but also decreased on testdiameter size. Moreover, the fishing ground is also to be distant from the localities. Thus, fishers need more effort and cost to catch sea urchins. Those indications are very strongly indicated the sign of 
overexploitation. According to Widodo and Suadi (2006), the characteristics of overfished are the time taken to go out to sea being longer, the fishing locations tending to be distant, the productivity or catch per unit effort tending to decrease, the size of the target fish is getting smaller, and the cost of the catching operations increasing.

Therefore, for answering the hypothesis, are sea urchins Tripneustes gratilla have overexploited at Wakatobi. This study was performed to verify the decreasing of sea urchin by measure the density and its test diameter. Thereby, this study is very important as part of an effort to manage the sea urchin resources, especially the sea urchin $T$. gratilla because there is no study at both study sites that have documented the impact of overfishing.

\section{Materials and Methods}

This study was conducted on August 2018 at Pulau Tomia $\left(38^{\circ} 8^{\prime} \mathrm{U}, 141^{\circ} 57^{\prime} \mathrm{T}\right)$ and Pulau Sawa $\left(38^{\circ} 8^{\prime} \mathrm{U}, 141^{\circ} 57^{\prime} \mathrm{T}\right)$, Wakatobi Regency, Southeastern Sulawesi, Indonesia (see Figure 1.). The seawater depth of both sites is $2 \mathrm{~m}$ depth at a hightide level, and $0.01 \mathrm{~m}$ at a low-tide level. The Sea bottom was dominated by seagrass beds with sandy substrate.

Sea urchin density at both sites was randomly collected using a $1 \mathrm{~m} \times 1 \mathrm{~m}$ transect quadrate with three replications along the seagrass beds when the seawater is retreading at the lowest level (approxi. $0.01 \mathrm{~m}$ in depth). Then, the number of sea urchins per quadrate was counted as density and noted on aqua-note.

In parallel with the density collection and measurement, each individual of sea urchin was measured with a caliper (accuracy $0.1 \mathrm{~mm}$ ) and noted. All statistical analyses were performed using
SPSS Statistic IBM 22® (SPSS Inc., Chicago, IL, USA). A significant difference among sea urchin density (ind. $\mathrm{m}^{-2}$ ) and its test diameter $(\mathrm{mm})$ between Pulau Sawa and Pulau Tomia were analyzed using $t$-test where the significant difference is $P<0.05$.

\section{Results and Discussion}

\section{Density}

There is a significant difference in sea urchin density between Pulau Sawa and Pulau Tomia $(P<$ $0.05)$. The densities (mean \pm SE) of the sea urchin Tripneustes gratilla at Sawa Pulau and Tomia Pulau are $10 \pm 0.6$ ind. $\mathrm{m}^{-2}$, and $2.7 \pm 0.9$ ind. $\mathrm{m}^{-2}$, respectively (see Figure 2.). Decreasing of sea urchin density at Pulau Tomia (inhabited area) and Pulau Sawa (uninhabited area) show that fishing pressure positively occurred, and it significantly reduced the number of sea urchins. The distance of fishing ground with fishers' resident seems to have a strong impact on that fishing pressure. It can be proved by the significant decrease of sea urchin number at Pulau Tomia compare to the sea urchin density at Pulau Sawa. These findings indicate that overfishing is truly happening. As a consequence, the urchin's number cannot recover immediately.

\section{Test diameter $(\mathrm{mm})$}

There is a significant difference in the test diameter of the sea urchin $T$. gratilla at both sites. Test diameter (mean \pm SE) at Pulau Sawa is $69.7 \pm 2.1$ $\mathrm{mm}$, and Pulau Tomia is $58.5 \pm 1.7 \mathrm{~mm}$ (see Figure 3.). According to Widodo and Suadi (2006), the indication of overfishing can be identified by decreasing fishing size. In parallel with these arguments, our finding also shows significant differences in the distribution of the sea urchin test. The average distribution of test diameter at Pulau Sawa is higher than the average of the sea urchin test diameter at Pulau Tomia.

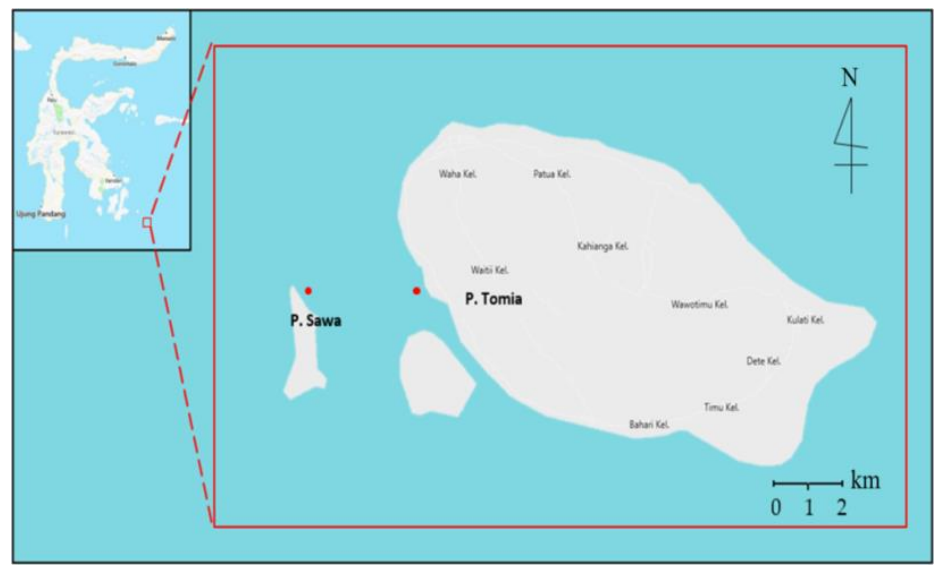

Figure 1. Study area. The red $\operatorname{dot}(\bullet)$ indicate the coordinate position of both study sites. 


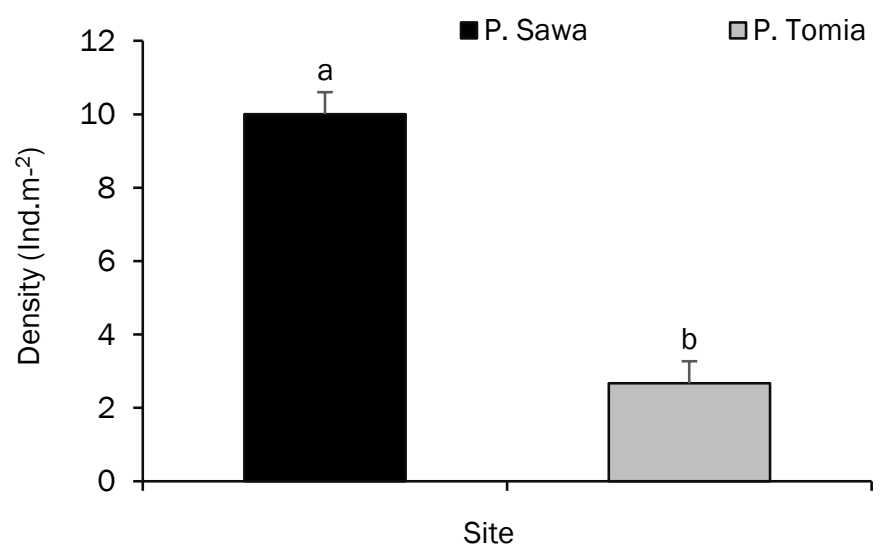

Figure 2. Densities (mean \pm SE) of sea urchin Tripneustes gratilla at both study sites. Different letter on the bar indicates significant difference $(P<0.05)$

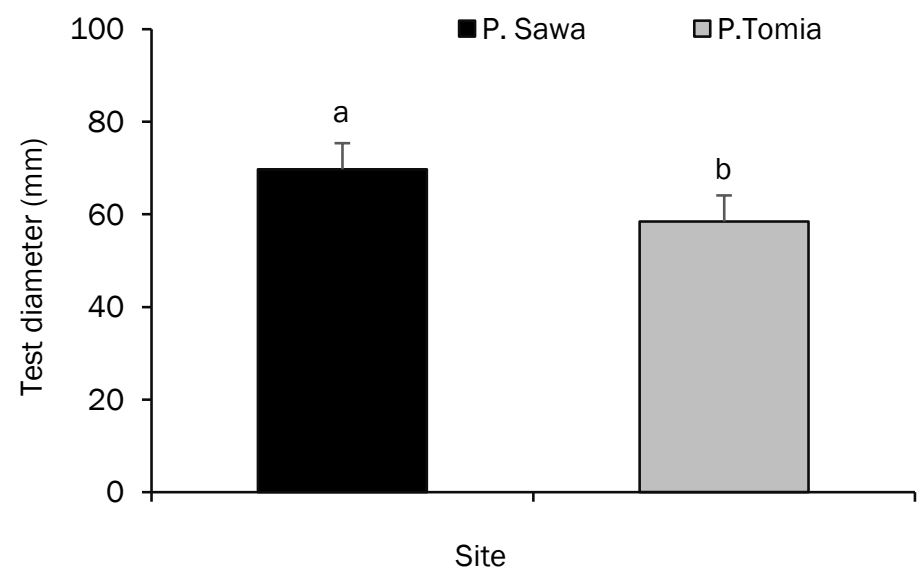

Figure 3. Test diameter difference (mean \pm SE) of the sea urchin Tripneustes gratilla from Pulau Sawa and Pulau Tomia. Different letter on the bar indicates significant difference $(P<0.05)$.
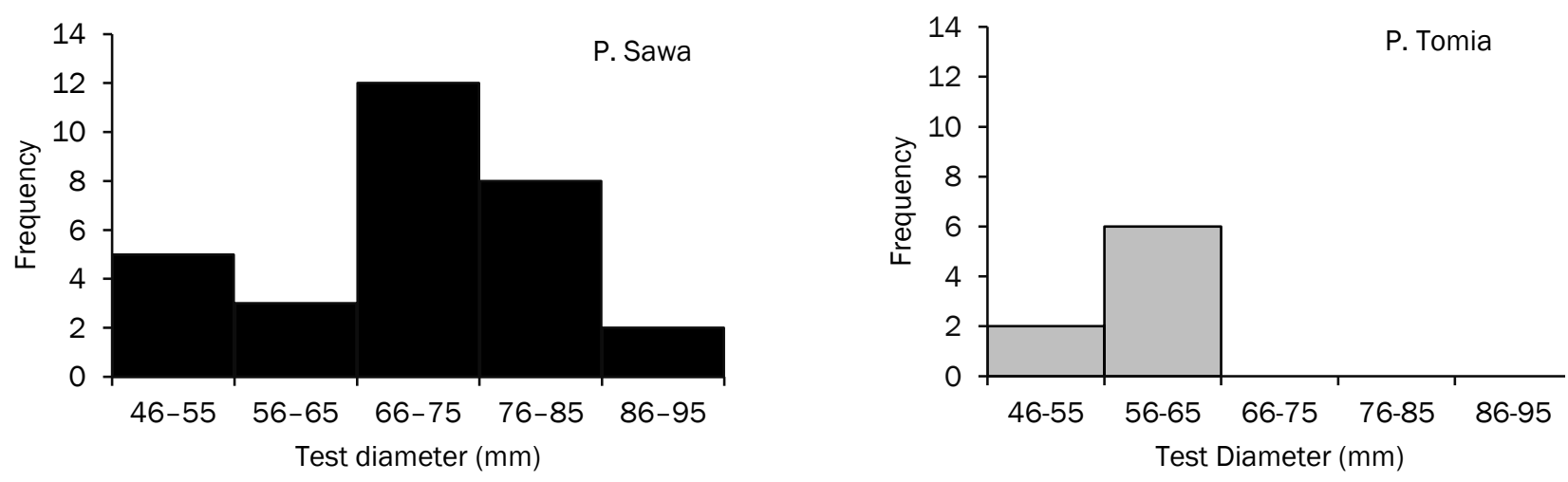

Figure 4. Differences in frequency distribution of sea urchin test diameter Tripneustes gratilla between Pulau Sawa and Pulau Tomia.

\section{Test diameter size-frequency}

The frequency distribution of the sea urchin test-diameter at both sites is different (see Figure 4.). According to Widodo and Suadi (2006), the indication of overfishing can be identified by decreasing fishing size. In parallel with these arguments, our finding also shows significant differences in the distribution of the sea urchin test. The average distribution of test diameter at Pulau Sawa is higher than the average of sea urchin test diameter at Pulau Tomia. The disappearance of sea urchin with test diameter size 
66-75 mm, 76-85 mm, and 86-95 $\mathrm{mm}$ at Pulau Tomia has revealed that sea urchins $T$. gratilla have overfished.

\section{Conclusion}

Decreasing of sea urchin number (density) and sea urchin test-diameter at Pulau Tomia that distant with fisher's resident than sea urchin at Pulau Sawa (uresident area) indicate that fishing activity was over. As a consequence, the size of sea urchin at Pulau Tomia is smaller than the sea urchin test diameter at Pulau Sawa due to recovery capability.

\section{References}

Andrew, N.L., Agatsuma, Y., Ballesteros, E., Bazhin, A.G., Creaser, E.P., Barnes, D.K., Botsford, L.W., Bradbury, A., Campbell, A., Dixon, J.D. \& Einarsson, S. 2002. Status and management of world sea urchin fisheries. Oceanog. Mar. Biol. Annual Rev. 40: 351-438. doi: 10.1201/9780203180594-26

Baião, L.F., Rocha, F., Costa, M., Sá, T., Oliveira, A., Maia, M.R. \& Valente, L.M. 2019. Effect of protein and lipid levels in diets for adult sea urchin Paracentrotus lividus (Lamarck, 1816). Aquaculture, 506:127-138. doi: 10.10 16/j.aquaculture.2019.03.005

Bronstein, O. \& Loya, Y. 2014. Echinoid community structure and rates of herbivory and bioerosion on exposed and sheltered reefs. J. Exp. Mar. Biol. Ecol., 456: 8-17. doi: 10.1016/j.jembe. 2014.03.003

Brown, P.N. \& Eddy, E.S. 2015. Echinoderm aquaculture. Wiley Blackwell, Hoboken. doi: 10.1002/9781119005810

Kato, S. 1972. Sea urchins: A new fishery develops in California. Mar. Fish. Rev., 34: 9-10.

Keesing, J.K. \& Hall, K.C. 1998. Urchin aquaculture: molecules to market- Review of harvests and status of world sea urchin fisheries points to opportunities for aquaculture. J. Shellfish Res., 17: 1597-1608.

Koike, I., Mukai, H. \& Nojima, S. 1987. The role of the sea urchin, Tripneustes gratilla (Linnaeus), in decomposition and nutrient cycling in a tropical seagrass bed. Ecol. Res. 2: 19-29. doi: 10.1007/BF02348616

Lawrence, J.M. 2007. Edible sea urchins: biology and ecology. Elsevier Science, Amsterdam.
Lesser, P. \& Walker, C.W. 1998. Introduction to the special section on sea urchin aquaculture. J. Shellfish Res., 17: 1505-1506.

Ling, S.D., Barrett, N.S. \& Edgar, G.J. 2018. Facilitation of Australia's southernmost reefbuilding coral by sea urchin herbivory. Coral Reefs, 37(4): 1053-1073. doi: 10.1007/s00 33 8-018-1728-4

Luza, J.C.S. \& Malay, M.C.M.D. 2019. Feeding preferences of the sea urchin Diadema setosum (Leske, 1778) in Taklong Island National Marine Reserve, Guimaras, Philippines. PeerJ Preprints, 7: e27733v1. doi: 10.7287/peerj. preprints.27733v1

Mos, B. \& Dworjanyn, S.A. 2019. Ready to harvest? Spine colour predicts gonad index and gonad colour rating of a commercially important sea urchin. Aquaculture, 505:510-516. doi: 10.101 6/j.aquaculture.2019.03.010

Robinson, S.M.C. 2004. The evolving role of aquaculture in the global production of sea urchins. Sea Urchins: Fisheries and Ecology (Lawrence, J.M. ed.), pp. 343-357. DEStech Publications Inc, Lancaster, PA, USA.

Salvo, A., Cicero, N., Vadalà, R., Mottese, A. F., Bua, D., Mallamace, D., Gianetto, C. \& Dugo, G. 2016. Toxic and essential metals determination in commercial seafood: Paracentrotus lividus by ICP-MS. Nat. Product Res., 30(6): 657-664. doi: 10.1080/1478641 9.2015.1038261

Sloan, N. 1985. Echinoderm Fisheries of the World: A Review, pp. 109-124. AA Balkema, Rotterdam, Amsterdam.

Steneck, R.S. 2013. Sea urchins as drivers of shallow benthic marine community structure. In: Lawrence JM (ed.) Sea urchins: biology and ecology. Elsevier, San Diego, pp 195-212. doi: 10.1016/B978-0-12-396491-5.00014-9

Sun, J. \& Chiang, F.S. 2015. Use and exploitation of sea urchins. In N. P. Brown, \& S. D. Eddy (Eds.). Echinoderm aquaculture (pp. 25-45).

Taylor, A.M., Heflin, L.E., Powell, M.L., Lawrence, A.L., \& Watts, S.A. 2017. Effects of dietary carbohydrate on weight gain and gonad production in small sea urchins, Lytechinus variegatus. Aquacul. Nutrition, 23(2): 375-386. doi: 10.1111/anu.12403

Widodo, J. \& Suadi 2006 Marine Fisheries Resource Management. Yogyakarta: Gajah Mada University Press., 252 pp. 